\title{
Clinical characterization of chronic chagasic cardiomyopathy in dogs ${ }^{1}$
}

\author{
João Paulo da E. Pascon² ${ }^{\star}$, Gláucia B. Pereira Neto², Marlos G. Sousa ${ }^{3}$, \\ Daniel Paulino Júnior ${ }^{2}$ and Aparecido A. Camacho ${ }^{4}$
}

\begin{abstract}
Pascon J.P.E., Pereira Neto G.B., Sousa M.G., Paulino Júnior D. \& Camacho A.A. 2010. Clinical characterization of chronic chagasic cardiomyopathy in dogs. Pesquisa Veterinária Brasileira 30(2):115-120. Departamento de Clínica e Cirurgia Veterinária, Faculdade de Ciências Agrárias e Veterinárias, Universidade Estadual Paulista, Jaboticabal, SP 14884-900, Brazil. E-mail: jpep23@yahoo.com.br

On the American continent, almost 15 million people are affected by Chagas disease, resulting in important economic and social damages. Dogs are considered to be an excellent experimental model to study Chagas' disease; as a result, in this research, the characterization of cardiovascular abnormalities was performed in dogs experimentally infected with Trypanosoma cruzi (the Colombian strain) that were at chronic stage. Thirteen adult female dogs were evaluated by electrocardiographic, echocardiographic, hematological and biochemical analyses in the chronic phase. For the electrocardiographic studies, respiratory sinus arrhythmia was the predominant rhythm during the entire research period $(49.55 \%$ to $67 \%$ ), with a low prevalence of right bundle branch block (0$13 \%)$ and first-degree atrioventricular block (0-14\%). The spectral Doppler echocardiography showed $E$ and $A$ mitral wave reversal $(0.71 \pm 0.17)$, confirming the diastolic dysfunction present in all dogs. An increase in the enzymes activities was detected in the serum analysis, indicating myocardial injury by the infection. Six dogs died during the follow-up. In this way, the clinical characterization of experimentally infected dogs, as described here, increases the knowledge and allows for recognition of the behavioural modifications present in Chagas' disease in affected dogs.
\end{abstract}

INDEX TERMS: Animal, Chagas disease, cardiomyopathy.

RESUMO.- [Caracterização clínica da cardiomiopatia chagásica crônica em cães.] No continente Americano, aproximadamente 15 milhões de pessoas são afetadas pela doença de Chagas, ocasionando importantes danos econômicos e sociais. O cão é considerado excelente modelo experimental para o estudo dessa enfermidade; assim sendo, foram caracterizadas, neste ensaio, as anormalidades

\footnotetext{
${ }^{1}$ Received on June 9, 2009.

Accepted for publication on August 6, 2009.

2 Departamento de Clínica e Cirurgia Veterinária, Faculdade de Ciências Agrárias e Veterinárias (FCAV), Universidade Estadual Paulista Júlio de Mesquita Filho (Unesp), Via de acesso "Prof. Dr. Paulo Donato Castellane" Km 5, Jaboticabal, SP 14884-900, Brazil. *Corresponding author: jpep23@yahoo.com.br

3 Universidade Federal do Tocantins, Rua Humberto de Campos 508, Bairro São João Centro, Araguaína, TO 77800-000, Brazil.

${ }^{4}$ Departamento de Clínica e Cirurgia Veterinária, FCAV-Unesp, Jaboticabal, SP.
}

cardiovasculares de 13 cães experimentalmente infectados com a cepa Colombiana do Trypanosoma cruzi, em fase crônica (1997-2004). Ao eletrocardiograma, a arritmia sinusal respiratória foi o ritmo predominante durante todo período experimental $(49,55-67 \%)$, com baixas prevalências de bloqueio de ramo direito $(0-13 \%)$ e de bloqueio atrioventricular de primeiro grau (0-14\%). A EcoDopplercardiografia espectral revelou inversão das ondas $E$ e A mitral $(0.71 \pm 0.17)$, confirmando a disfunção diastólica presente em todos os cães avaliados. O aumento da atividade enzimática sérica foi detectado, indicando agressão miocárdica pela infecção. Seis cães morreram durante o período experimental. Desta forma, a caracterização clínica dos cães experimentalmente infectados trouxe informações importantes, possibilitando reconhecer o comportamento clínico dessa importante infecção, na espécie canina.

TERMOS DE INDEXAÇÃO: Animal, doença de Chagas, cardiomiopatia 


\section{INTRODUCTION}

Currently 15 million people living between Mexico and Argentina are affected by Chagas' disease, and 28 million are at a high risk of developing it (WHO 2007). This disease is considered one of the most important health problems in South and Central America (Prata 1994). The globalisation plays a significant role in the disease dissemination, which is proven by the serologic estimation that half million people are positive for Chagas' disease in the United States of America (Wanderley \& Corrêia 1995, Marin-Neto et al. 1999).

For human beings, the dog may be a sentry and a host of Chagas' disease, deserving of more attention in the scientific community. Concerning this importance and the lack of knowledge about this disease in the canine species, the purpose of this study was evaluate the clinical behaviour of this illness in dogs during eight years of chronic infection by Trypanosoma cruzi, the Colombian strain. One of the main reasons for this research is prepare clinicians to recognise this prevalent disease in the canine species, in order to prevent the death and transmission to other dogs or their owners.

\section{MATERIALS AND METHODS}

\section{Chronic chagasic cardiomyopathy induction}

A total of 13 adult female dogs were inoculated intraperitoneally with Trypanosoma cruzi, the Colombian strain, at 1.000 trypomastigotes per kilogram of body weight. Before the inoculation and during the indeterminate chronic phase, the indirect fluorescent antibody test at the dilutions of 1:20 to 1:5120 was performed in all dogs. Each negative serum-control was diluted to $1: 40$.

\section{Cardiovascular evaluation}

Every 30 or 60 days over the course of eight years (19972004), the dogs were examined by electro-cardiography (Tilley 1992). At the end of the experimental period (2004), Doppler echocardiography (Boon 1998) and dynamic electrocardiography (Moïse \& Defrancesco 1995) were performed in the seven remaining dogs (six of the dogs died during the research study).

\section{Haematological and biochemical tests}

Blood samples were collected from jugular puncture every 30 or 60 days for haematological analysis. The serum activities of the enzymes aspartate transaminase (AST), creatine kinase (CK) and lactate dehydrogenase (LDH) were evaluated in the year 2004 using spectrophotometry, according to the Labtest methodology ${ }^{5}$, with the colorimetric read ${ }^{5}$ in the visible strip.

\section{Statistical analysis}

The conventional electrocardiographic and hematologic data were submitted to variance analysis (ANOVA), and their annual averages were compared by the Tukey test with a $95 \%$ probability. The rhythms were organised as a percentage and analysed descriptively.

\section{Ethics}

The present study was approved by the ethics committee for animal use, for respecting the criteria adopted by the Brazilian school of experimentation (Protocol number: 017551-07).

\section{RESULTS}

\section{Conventional and dynamic electrocardiography}

Respiratory sinus arrhythmia was the predominant rhythm during this assay period, accompanied by abnormalities of impulse conduction (right bundle branch block, RBBB, and ventricular conduction disturbance, VCD) and first-degree atrioventricular block (Fig.1, Table 1).

A decrease in the QRS complex amplitude was observed, varying in proportion from $10 \%$ to $27.3 \%$ of the annual averages. The electrocardiographic evaluation, using the P wave, QT interval and heart rate, showed no

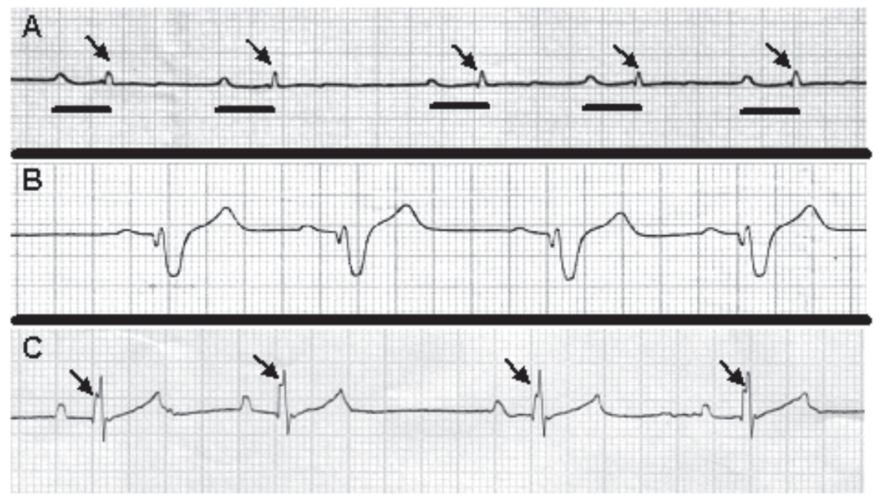

DII, $50 \mathrm{~mm} / \mathrm{s}, 1 \mathrm{~cm}=1 \mathrm{mV}$

Fig.1. Electrocardiogram of three experimented dogs. $A$ shows the QRS complex amplitude decrease (arrow), respiratory sinus arrhythmia and first-degree atrioventricular block (line). $B$ demonstrates the right bundle branch block. $C$ presents the ventricular conduction disturbance (arrow) and millivoltage suppression.

Table 1. Percentage (\%) of rhythm and abnormalities of impulse conduction (RBBB and VCD) recorded on the electrocardiogram of 13 adult female dogs with chronic Chagas' disease (1997-2004)

\begin{tabular}{ccccccccc}
\hline Rhythm $^{\mathrm{a}}$ & 1997 & 1998 & 1999 & 2000 & 2001 & 2002 & 2003 & 2004 \\
\hline RSR & 14.3 & 7.2 & 3.8 & 7.5 & 4.4 & 9.3 & 5.6 & 0 \\
RSA & 49.5 & 53.7 & 54.8 & 63.4 & 54.3 & 67 & 62.5 & 57.1 \\
MP & 9.8 & 14.5 & 10.3 & 8.1 & 7.2 & 5 & 7 & 0 \\
AVB 1ㅇ & 0 & 0 & 0.7 & 3.7 & 4.4 & 6 & 8.3 & 14.3 \\
AVB 2ㅇ I & 0 & 0 & 0 & 0 & 0.7 & 0 & 0 & 0 \\
AVB 2이 II & 0 & 0 & 0 & 0 & 0.7 & 0 & 0 & 0 \\
ST & 17.6 & 12.6 & 18.5 & 6.8 & 12.4 & 6.8 & 8.3 & 28.6 \\
APC & 0 & 0.6 & 0 & 0 & 0 & 0 & 0 & 0 \\
VPC & 0 & 5.4 & 4.4 & 1.2 & 0 & 0.8 & 1.3 & 0 \\
SA & 0 & 0 & 0 & 0.6 & 0 & 0.8 & 0 & 0 \\
RBBB & 7.7 & 6 & 7.5 & 5.6 & 13 & 1.7 & 0 & 0 \\
VCD & 1.1 & 0 & 0 & 3.1 & 2.9 & 2.6 & 7 & 0
\end{tabular}

a RSR = regular sinus rhythm; RSA = respiratory sinus arrhythmia; MP $=$ migratory pacemaker; AVB $1^{\circ}=$ first-degree atrioventricular block; AVB 2 I = second-degree atrioventricular block, Mobitz I; AVB $2 ㅇ I I=$ second-degree atrioventricular block, Mobitz II; ST = sinus tachycardia; $\mathrm{APC}=$ atrial premature complex; VPC = ventricular premature complex; $\mathrm{SA}=$ sinus arrest; RBBB = right bundle branch block; $\mathrm{VCD}=$ ventricular conduction disturbance.

\footnotetext{
${ }^{5}$ Labquest $\circledast$, Labtest, Avenida Paulo Ferreira da Costa 600, Lagoa Santa, MG.
} 
Table 2. Annual averages of heart rate, QRS and QT interval durations, as recorded on the electrocardiogram of 13 adult female dogs with chronic Chagas' disease (1997-2004)

\begin{tabular}{ccccccccccc}
\hline & NV & 1997 & 1998 & 1999 & 2000 & 2001 & 2002 & 2003 & 2004 & Average/VC\% \\
\hline QRS & 0.055 & $0.0526^{\mathrm{ab}}$ & $0.0513^{\mathrm{ab}}$ & $0.0516^{\mathrm{ab}}$ & $0.0503^{\mathrm{ab}}$ & $0.0555^{\mathrm{a}}$ & $0.0514^{\mathrm{ab}}$ & $0.0488^{\mathrm{bc}}$ & $0.0429^{\mathrm{c}}$ & $0.0517 / 16.67 \%$ \\
QT & $0.15-0.25$ & $0.1860^{\mathrm{a}}$ & $0.1885^{\mathrm{a}}$ & $0.1868^{\mathrm{a}}$ & $0.1929^{\mathrm{a}}$ & $0.1943^{\mathrm{a}}$ & $0.1895^{\mathrm{a}}$ & $0.1861^{\mathrm{a}}$ & $0.1929^{\mathrm{a}}$ & $0.1897 / 7.40 \%$ \\
HR & $70-160$ & $127^{\mathrm{a}}$ & $123^{\mathrm{a}}$ & $129^{\mathrm{a}}$ & $119^{\mathrm{a}}$ & $125^{\mathrm{a}}$ & $122^{\mathrm{a}}$ & $120^{\mathrm{a}}$ & $131^{\mathrm{a}}$ & $124 / 14.77 \%$
\end{tabular}

Small letters = comparison between averages of the same line by Tukey test $(P<0.05)$; NV $=$ normality values (Tilley 1992); VC = variation coefficient; QRS = duration of the QRS complex (in seconds); QT = duration of the QT interval (in milliseconds); $\mathrm{HR}=$ heart rate (in bpm).

Table 3. Individual, average and standard deviation values (mean \pm SD) for the Holter electrocardiography of seven adult female dogs with chronic Chagas' disease

\begin{tabular}{|c|c|c|c|c|c|c|c|c|}
\hline \multirow[t]{2}{*}{ Animal } & \multirow{2}{*}{$\begin{array}{c}\text { QRS } \\
\text { frequency }\end{array}$} & \multicolumn{3}{|c|}{ Heart rate (bpm) } & \multirow[t]{2}{*}{ VPCa } & \multirow[t]{2}{*}{ APC } & \multicolumn{2}{|c|}{ Pauses } \\
\hline & & Maxim & Average & Minimum & & & Number & $\begin{array}{l}\text { Duration } \\
\text { (seconds) }\end{array}$ \\
\hline M1 & 18485 & 203 & 83 & 42 & 8 & 0 & 0 & 0 \\
\hline M4 & 174799 & 250 & 124 & 63 & 55 & 0 & 0 & 0 \\
\hline M5 & 101072 & 240 & 104 & 62 & 1 & 0 & 0 & 0 \\
\hline M8 & 144133 & 190 & 106 & 62 & 1162 & 2 & 0 & 0 \\
\hline M10 & 84609 & 169 & 61 & 35 & 1 & 0 & 175 & 2,8 \\
\hline R1 & 84217 & 226 & 87 & 36 & 47 & 0 & 463 & 3,0 \\
\hline $\mathrm{R} 2$ & 105529 & 250 & 83 & 43 & 1 & 0 & 129 & 2,8 \\
\hline \multirow[t]{2}{*}{ Mean $\pm \mathrm{SD}$} & 101834.85 & 218.28 & 92.57 & 49.0 & 165.2 & 0.2 & 109.57 & 1,2 \\
\hline & \pm 49466.23 & \pm 31.63 & \pm 20.45 & \pm 12.80 & \pm 432.6 & \pm 0.75 & \pm 172.04 & \pm 1.53 \\
\hline
\end{tabular}

$\overline{\mathrm{aVPC}}=$ ventricular premature contraction; $\mathrm{APC}=$ atrial premature contraction.

average differences during the experimental period (Tukey, $p>0.05)$. Although a few temporal variations were present concerning other electrocardiographic parameters, they were not considered clinically relevant (Table 2).

The dynamic electrocardiography (Holter system) showed a large individual variation over 24 hours in the complex QRS frequency (174.799 to 18.485), heart rate (250 to $35 \mathrm{bpm}$ ), and ventricular (VPC) and atrial (APC) premature complexes. The frequency and duration of pauses over 24 hours was noticed, in particular, for one dog (M8), who had 1,162 VPC and 2 APC (Table 3).

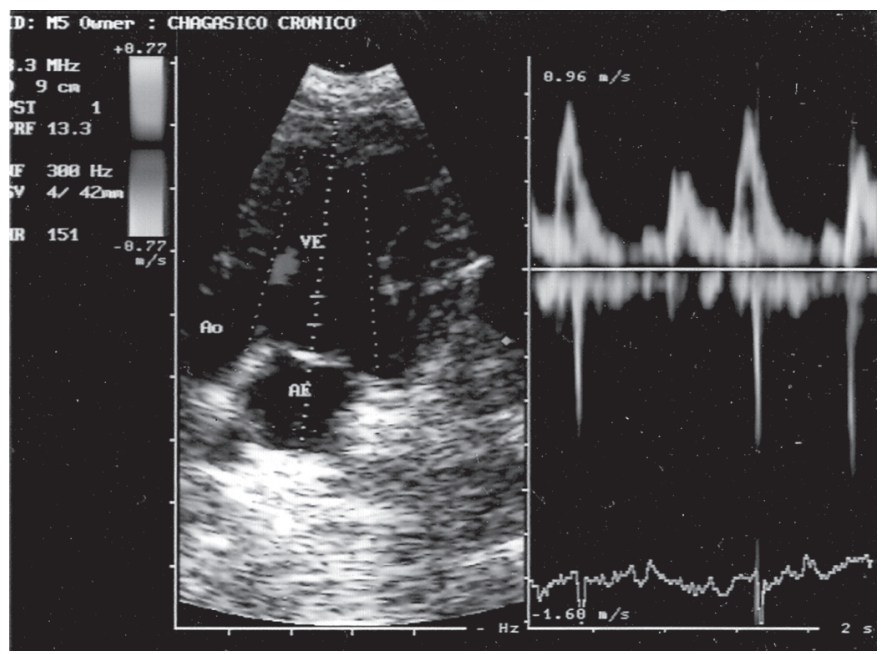

Fig.2. Pulsed-wave Doppler recording of transmitral $E$ and $A$ waves, showing the reversal $E / A$ ratio (diastolic dysfunction). $A E=$ left atrium; $V E=$ left ventricle; $A O=$ aorta.

\section{Haematology and serum biochemical analysis}

During the years, no relevant alterations in the hematological analysis were noticed in the infected dogs. However, all dogs showed an increase in the serum activity of the CK enzyme, reaching a medium value of $457.57 \pm$ $720.27 \mathrm{U} / \mathrm{L}$. Although at a lower intensity, other parameters like LDH (429.28 $\pm 256.17 \mathrm{U} / \mathrm{L})$ and AST (41.16 $\pm 28.61 \mathrm{U} /$ $\mathrm{mL})$ were also increased.

\section{Doppler echocardiography}

Diastolic dysfunction was the most frequent disorder observed, identified by E/A transmitral wave reversal of the Doppler spectral ratio (Fig.2 and Table 4) and hypokinesis of the interventricular septum (Fig.3). Cardiomegaly was not detected in this evaluation. The Mmode-derived parameters are shown in Table 5.

\section{DISCUSSION}

The main electrocardiographic alterations observed in this research included first-degree AVB, decrease in the QRS complex amplitude and RBBB, as also described in dogs (Barr et al. 1992, Klein 1995, Meurs et al. 1998, Camacho et al. 2000, Marin-Neto et al. 2000), and in humans (Nunes et al. 2004).

However, in contrast to what was observed in the present study, Nunes et al. (2004) and Marin-Neto et al. (2000) highlighted the high incidence of electrical conduction disturbance in the male heart (in particular RBBB), and they considered this as a strong indicator of Chagas' disease in endemic regions. Nevertheless, in this assay, conduction disturbances had an annual incidence from $0 \%$ 
Table 4. Individual, average and standard deviation values (mean \pm $\mathrm{SD})$ of the mitral $E$ and $A$ wave velocity peak $(\mathrm{m} / \mathrm{s})$ and E/A ratio on

Doppler echocardiography, which was obtained from the left parasternal 4-chamber views of seven adult female dogs with chronic Chagas' disease

\begin{tabular}{|c|c|c|c|c|c|c|c|c|c|}
\hline & \multirow[t]{2}{*}{ NV } & \multicolumn{7}{|c|}{ Animals } & \multirow[t]{2}{*}{ mean $\pm S D$} \\
\hline & & M8 & $\mathrm{R} 1$ & $\mathrm{R} 2$ & M1 & M4 & M5 & M10 & \\
\hline$E$ & & 0.45 & 0.5 & 0.43 & 0.46 & 0.55 & 0.43 & 0.57 & \\
\hline$A$ & $0.33-0$ & 0.68 & 0.74 & 0.63 & 0.64 & 0.82 & 0.73 & 0.51 & 0.09 \\
\hline$E / A$ & $1.04-2.42$ & 0.66 & 0.67 & 0.63 & 0.71 & 0.67 & 0.58 & 1.11 & $0.71 \pm 0.17$ \\
\hline Weight (kg) & - & 10.8 & 12 & 15.5 & 16.4 & 8.3 & 6.7 & 11.8 & $11.64 \pm 3.51$ \\
\hline
\end{tabular}

$\mathrm{E}$ = peak flow velocity of mitral $\mathrm{E}$ wave; $\mathrm{A}=$ peak flow velocity of mitral $\mathrm{A}$ wave; $\mathrm{E} / \mathrm{A}=$ mitral $E$ and $A$ wave ratio; NV = normality values (Boon 1998).

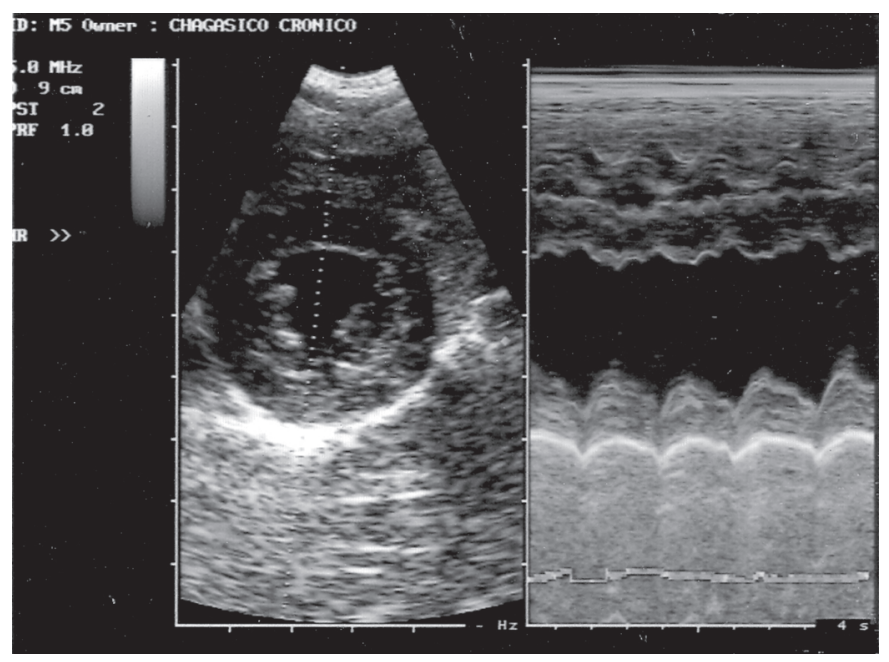

Fig.3. M-mode echocardiography, demonstrating hypokinesis of the interventricular septum.

Table 5. M-mode-derived parameters (mean $\pm \mathrm{SD}$ ) in dogs with chronic Chagas' disease

\begin{tabular}{cc}
\hline LVs & $1.81 \pm 0.18$ \\
LVd & $3.04 \pm 0.027$ \\
IVSs & $1.13 \pm 0.22$ \\
IVSd & $0.82 \pm 0.06$ \\
FWs & $1.21 \pm 0.14$ \\
FWd & $0.86 \pm 0.17$ \\
$\% E F$ & $40 \pm 9.25$ \\
$\% F S$ & $71.14 \pm 10.96$ \\
weight (kg) & $11.64 \pm 3.51$ \\
& \\
LVs = left-ventricular end-systolic dimension (in \\
centimetres); LVd = left-ventricular end-diastolic \\
dimension (in centimetres); IVSs = interventricular septal \\
thickness in systole (in centimetres); IVSd = interventri- \\
cular septal thickness in diastole (in centimetres); FWs \\
= left-ventricular free wall thickness in systole (in \\
centimetres); FWd = left-ventricular free wall thickness \\
in diastole (in centimetres); \%EF = ejection fraction (in \\
\%); \%FS = fractional shortening (in \%).
\end{tabular}

to $13 \%$, which was not in the same proportions as those described by the aforementioned authors.

In veterinary medicine, the low prevalence of those conduction disturbances was also reported (Meurs et al. 1998, Montenegro et al. 2002, Alves 2003). Using elec-tronic microscopy, researchers have identified focal regions of chronic myocarditis with myocytes substitution for fat and collagen tissue (Andrade et al. 1997). The most affected part of the heart in chronically chagasic dogs corresponded to the specialised atrioventricular conduc-tion system and bundle of His, justifying the electrocardio-graphic abnormalities found in the present research. The same association between myocardial injuries and electric changes was previously described (Barr et al. 1992, Tilley 1992).

Although the annual averages were included in the standard patterns, the decreases in the QRS complex amplitude values were individually observed. This electric effect was attributed to myocarditis followed by fibrosis, as developed by human beings and dogs with chagasic cardiomyopathy (Barr et al. 1992, Lana et al. 1992, Meurs et al. 1998, Camacho et al. 2000, Marin-Neto et al. 2000, Caliari et al. 2002, Montenegro et al. 2002, Alves 2003).

Even though respiratory sinus arrhythmia was the most prevalent rhythm every year, sinus tachycardia was also found at an annual percentage varying from $6.8 \%$ to $28.6 \%$ of the dogs during the experimental protocol, corroborating the information from Barr et al. (1992) and Montenegro et al. (2002). No difference was detected between this rhythm and casualties, once the momentary stress caused a transitory increase on the heart rate (Tilley 1992).

The dynamic electrocardiography (Holter system) was effective for the detection of rhythm disturbances, like ventricular trigeminy and sinus arrest. These types of disturbances were also described before (Grupi et al. 1994), as a significant individual variation that was detected in the Holter analysis (Alves 2003).

Concerning the hematological evaluation, no important alterations were found. Most likely, the chronic adaptation to the illness allowed the normalisation of hematological parameters, as was also seen in other organic functions, including the cardiac function itself in some cases (SterinBorda \& Borda 1994).

Serum activities of the tested enzymes were significantly increased (CK, LDH and AST), indicating myocardial compromise, and the dogs had no clinical signs of muscular, bony or liver injury at the time of these analysis. Different descriptions were made with the same strain of Trypanosoma cruzi (Klein 1995), and with Bolivian 
strain (Alves 2003); they observed an increase in these enzyme serum activities only during the first months of the indeterminate chronic phase after experimental infection in dogs. However, it should be noted that studies presented a shorter period of evaluation than the present one, and the one developed with the Bolivian strain showed a different behaviour, which was much more aggressive than the Colombian strain.

It is important to consider that one dog (M10) had higher values of enzymatic serum activity than the others, thereby increasing the average value. Even so, the activity of CK was higher than normal in all experimental dogs, and only one dog (M8) showed no elevated activity of LDH. Therefore, these results emphasise the important myo-cardial damage verified even in the indeterminate phase of chagasic cardiomyopathy, with the Colombian strain, in dogs. As previously mentioned, direct parasitic activity is not responsible for cardiac damage in the chronic phase of the disease. Cardiac injury may occur, however, due to other several mechanisms, including the cellular and humoral immune response, in addition to inflammatory and autoimmune components (Andrade et al. 1997, Andra-de 1999, Soares et al. 2001, Caliari et al. 2002, Ferreira 2003).

The echocardiography was a safe and efficient technique to evaluate the hemodynamic function of chronic chagasic dogs. The diastolic dysfunction of the left ventricle, as diagnosed by standard E/A transmitral wave reversal in the Doppler spectral ratio, was the most consistent abnormality observed, as already reported (Barros et al. 2002, Alves 2003, Carot-Artal et al. 2003). During the asymptomatic period of human infection, Doppler echocardiography has singular importance, since it is able to identify suggestive changes, even when the electrocardiogram is normal (Marin-Neto et al. 2000). It permits the detection of diastolic dysfunction prior to systolic dysfunction (Marques et al. 2006), as observed in our dogs. Chagasic myocarditis causes focal damage to myocardial fibres, framework system components, interstitial, specialised conduction system and vascular integrity, resulting in ventricular dysfunction detectable by Doppler echocardiography (Barros et al. 2002).

Different degrees of cardiomegaly may be noticed in the echocardiography of chagasic animals (Meurs et al. 1998, Alves 2003) and human beings (Barros et al. 2002, Carod-Atal et al. 2003, Nunes et al. 2004). However, in this study, we had no evidence of chambers dilatation, which characterises the Colombian strain diastolic dysfunction behaviour that induces myocardial fibrosis. Hypokinesis of interventricular septum was observed in all dogs, in agreement with Alves (2003), who studied infected dogs, and Borges-Pereira et al. (1998) and Marques et al. (2006), who studied human beings chronically affected by Chagas disease.

\section{CONCLUSIONS}

Considering the conditions that this study accomplished, it is possible to conclude that dogs in the chronic phase of
Chaga' cardiomyopathy, caused by the Colombian strain, present small abnormalities of impulse conduction verified by electrocardiography (conventional and dynamic), associated with diastolic dysfunction as detected by Doppler echocardiography. Myocardial injury, as suggested by biochemical analysis, was not followed by hematological alterations.

The chronic chagasic myocardiopathy, achieved by the experimental infection of adult dogs, was preceded by a variable indeterminate phase without clinical signs, which makes diagnosis during this period difficult. As observed in human beings, the transition between the asymptomatic and chronic cardiac stage is obscure and unpredictable, highlighting the importance of this long term research and the dog as a good experimental model because of its similarities with the human disease.

In the beginning of this assay, some technologies, such as Doppler echocardiography, the Holter system and specific biomarkers of myocardial damages, were not available. Some of these auxiliary tools became available at the end of the study, and the evolution parameters could not be analysed. Despite these limitations, the present research provides unique information about Chagas' disease in dogs, giving a better knowledge of this important infection.

\section{REFERENCES}

Alves R.O. 2003. Avaliações ecodopplercardiográfica, eletrocardiográfica computadorizada e dinâmica (sistema Holter) e clínico-patológica em cães com cardiomiopatia chagásica experimental. Tese de Doutorado, Faculdade de Ciências Agrárias e Veterinárias, Universidade Estadual Paulista, Jaboticabal, SP. 134p.

Andrade Z.A., Andrade S.G., Sadigursky M., Wenthold R.J., Hilberg S.L. \& Ferrans V.J. 1997. The indeterminate phase of Chagas' disease: Ultrastructural characterization of cardiac changes in the canine model. Am. J. Trop. Hyg. 57:328-336.

Andrade Z.A. 1999. Immunopathology of Chagas' disease. Mem. Inst. Oswaldo Cruz 94:71-80.

Barr S.C., Holmes R.A. \& Klei T.R. 1992. Electrocardiographic features of trypanosomiasis in dogs inoculated with North American Trypanosoma cruzi isolates. Am. J. Vet. Res. 53:521-527.

Barros M.V.L., Machado F.S., Ribeiro A.L.P. \& Rocha M.O.C. 2002. Detection of early right ventricular dysfunction in Chagas' disease using Doppler tissue imaging. J. Consult. Clin. Psychol. 15:1197-1201.

Boon J.A. 1998. Manual of Veterinary Echocardiography. Williams and Wilkins, Baltimore. 478p.

Borges-Pereira J., Xavier S.S., Pirmez C. \& Coura J.R. 1998. Doença de chagas em Virgem da Lapa, Minas Gerais, Brasil. IV. Aspectos clínicos e epidemiológicos do aneurisma ventricular esquerdo. Revta Soc. Bras. Med. Trop. 31:457-463.

Caliari M.V., Machado R.P., Lana M., Cajá R.A.F., Carneiro C.M., Bahia M.T., Santos C.A.B., Magalhães G.A., Sampaio I.B.M. \& Tafuri W.L. 2002. Quantitative analysis of cardiac lesions in chronic canine chagasic cardiomyopathy. Revta Inst. Med. Trop. 44:273-278.

Camacho A.A., Teixeira M.S.S. \& Alves R.O. 2000. Electrocardiography in adult dogs infected with Trypanosoma cruzi during acute and chronic phases. Ars Vet. 16:158-164.

Carod-Artal F.J., Melo P. \& Horan T.A. 2003. American trypanosomiasis (Chagas' disease): An unrecognised cause of stroke. J. Neurol. Neurosurg. Psychiatr. 74:516-518. 
Ferreira R.C., Lanni B.M., Abel L.C.J., Buck P., Mandy C., Kalil J. \& Cunha-Neto E. 2003. Increased plasma level of tumor necrosis factor$\alpha$ and Chagas disease cardiomyopathy patients. Mem. Inst. Oswaldo Cruz 98:407-411.

Grupi J.G., Moffa P.J., Barbosa S.A., Sanches P.C., Barragan Filho E.G., Bellotti G.M.V. \& Pileggi F.J.C. 1994. O eletrocardiograma de longa duração (Holter) na doença de Chagas. Revta Soc. Cardiol. 4:163-167.

Klein R.P. 1995. Avaliação clínica e contagem neuronal em gânglios nervosos cardíacos em cães experimentalmente infectados com Trypanosoma cruzi. Dissertação de Mestrado, Faculdade de Ciências Agrárias e Veterinárias, Universidade Estadual Paulista, Jaboticabal, SP. 109p.

Lana M., Chiari E. \& Tafuri W.L. 1992. Experimental Chagas' disease in dogs. Mem. Inst. Oswaldo Cruz 87:59-71.

Marin-Neto J.A., Simões M.V. \& Sarabenda A.V.L. 1999. Cardiopatia chagásica. Arq. Bras. Cardiol. 72:247-263.

Marin-Neto J.A., Simões M.V. \& Sarabanda A.V.L. 2000. Forma crônica cardíaca, p.266-296. In: Brener Z., Andrade Z.A. \& Barral-Neto M. (Eds), Trypanosoma cruzi e doença de Chagas. 2a ed. Guanabara Koogan, Rio de Janeiro.

Marques D.S.O., Canesin M.F., Júnior F.B., Fuganti C.J. \& Barreto A.C.P. 2006. Avaliação de pacientes assintomáticos com forma crônica da doença de Chagas através da análise do eletrocardiograma dinâmico, ecocardiograma e do peptídeo natriurético tipo B. Arq. Bras. Cardiol. 87:336-343.

Meurs K.M., Anthony M.A., Slater M. \& Miller M.W. 1998. Chronic Trypa- nosoma cruzi infection in dogs: 11 cases (1987-1996). J. Am. Vet. Med. Assoc. 213:497-500.

Moïse S.M. \& Defrancesco T. 1995. Twenty-four-hour ambulatory electrocardiography (holter monitoring), p.792-799. In: Bonagura,J.D. \& Kirk R.W. (Eds), Current Veterinary Therapy. Small Animal Practice. XII. W.B. Saunders, Philadelphia.

Montenegro V.M., Jiménez M., Dias J.C.P. \& Zeledón R. 2002. Chagas disease in dogs from endemic areas of Costa Rica. Mem. Inst. Oswaldo Cruz 97:491-494.

Nunes M.C.P., Barbosa M.M., Brum V.A.A. \& Rocha M.O.C. 2004. Morphofunctional characteritics of the right ventricle in Chagas' dilated cardiomyopathy. Int. J. Cardiol. 94:79-85.

Prata A. 1994. Chagas' disease. Infect Dis. Clin. North Am. 8:61-76.

Soares M.B.P., Pontes-De-Carvalho L. \& Ribeiro-dos-Santos R. 2001. The pathogenesis of Chagas' disease: When autoimmune and parasite-specific immune responses meet. Anais Acad. Bras. Ciênc. 73:547-559.

Sterin-Borda L.J. \& Borda E.S. 1994. Participation of autonomic nervous system in the pathogenesis of Chagas disease. Acta Physiol. Pharmacol. Ther. Latinoam. 44:109-23.

Tilley L.P. 1992. Essentials of Canine and Feline Electrocardiography. $3^{\text {rd }}$ ed. Lea and Febiger, Philadelphia. 470p.

Wanderley D.V.M. \& Corrêa F.M.A. 1995. Epidemiology of Chagas' heart disease. São Paulo Med. J. 113:742-749.

WHO 2007. Reporte del grupo de trabajo cientifico sobre la enfermidad de Chagas (TDR/SWG/09). World Health Organization, Argentina. $104 p$. 